\title{
АРХИВ
}

БАРБЕНКО Ярослав Александрович

канд. ист. наук, доцент кафедры политологии Восточного института - Школы региональных и международных исследований, ДВФУ (г. Владивосток)

Электронная почта: prohist@ya.ru

\section{Материалы обследования кафедры китайского языка ДВГУ, декабрь 1935 - январь 1936 годов. Часть 1}

DOI https://doi.org/10.24866/2542-1611/2021-1/89-113

\author{
Памяти Элеоноры Васильевны Ермаковой \\ и Ольги Павловны Еланиевой - \\ деятельных исследователей истории университета
}

«Известия Восточного института» в четырёх выпусках 2021 года публикуют цикл документов, связанный с драматическими страницами истории Дальневосточного университета и отечественной высшей школы в целом. 30-е годы XX века начались с крупных реформ и шатаний в сфере образования, а закончились массовыми репрессиями по всей стране, в том числе и в высшей школе. В 1930 г. в целях более эффективной специализации подготовки кадров для народного хозяйства был расформирован ряд крупных вузов РСФСР, в том числе и Государственный дальневосточный университет во Владивостоке, на базе факультетов которого было создано пять вузов во Владивостоке и Хабаровске, а в близкой перспективе их число должно было удвоиться [2, с. 107]. Восточный факультет вошёл в состав Дальневосточного института народного хозяйства в Хабаровске [2, с. 107]. Реформа проблем образования не решала, зато создавала новые, что побудило СНК в 1931 г. принять решение о восстановлении упразднённых университетов, в том числе и дальневосточного (теперь под названием «Дальневосточный государственный университет»), в состав которого вошёл и восточный факультет [2, с. 108]. Однако восстановление университета не означало упразднения институтов, выделившихся из него, что обостряло и без того непростую ситуацию с материальным и кадровым обеспечением высшей школы: у университета первое время практически не было помещений, библиотека была в нерабочем состоянии [2, c. 108-109].

В последующие годы материальные условия работы преподавателей и студентов последовательно улучшались, чего не сказать об организационной стороне, осложнявшейся и политическим содержанием. Так, с 1932 г. в связи с отказом от практикоориентрованного бригадно-лабораторного метода обучения 20-х гг. и обращением к более академичной и теоретически насыщенной системе, подразумевавшей упор на лекционные формы занятий, активно пересматривались учебные программы, была усилена языковая подготовка специалистов-восточников; с 1933 г. в образовательный процесс внедряется культура соревнования [2, с. 110-113]. Пусть эта работа не покажется

Для иитирования:

Барбенко Я. А. Материалы обследования кафедры китайского языка ДВГУ, декабрь 1935 - январь 1936 годов. Часть 1 // Известия Восточного института. 2021. № 1 . C. 89-113. DOI https://doi. org/10.24866/2542-1611/2021$1 / 89-113$ 


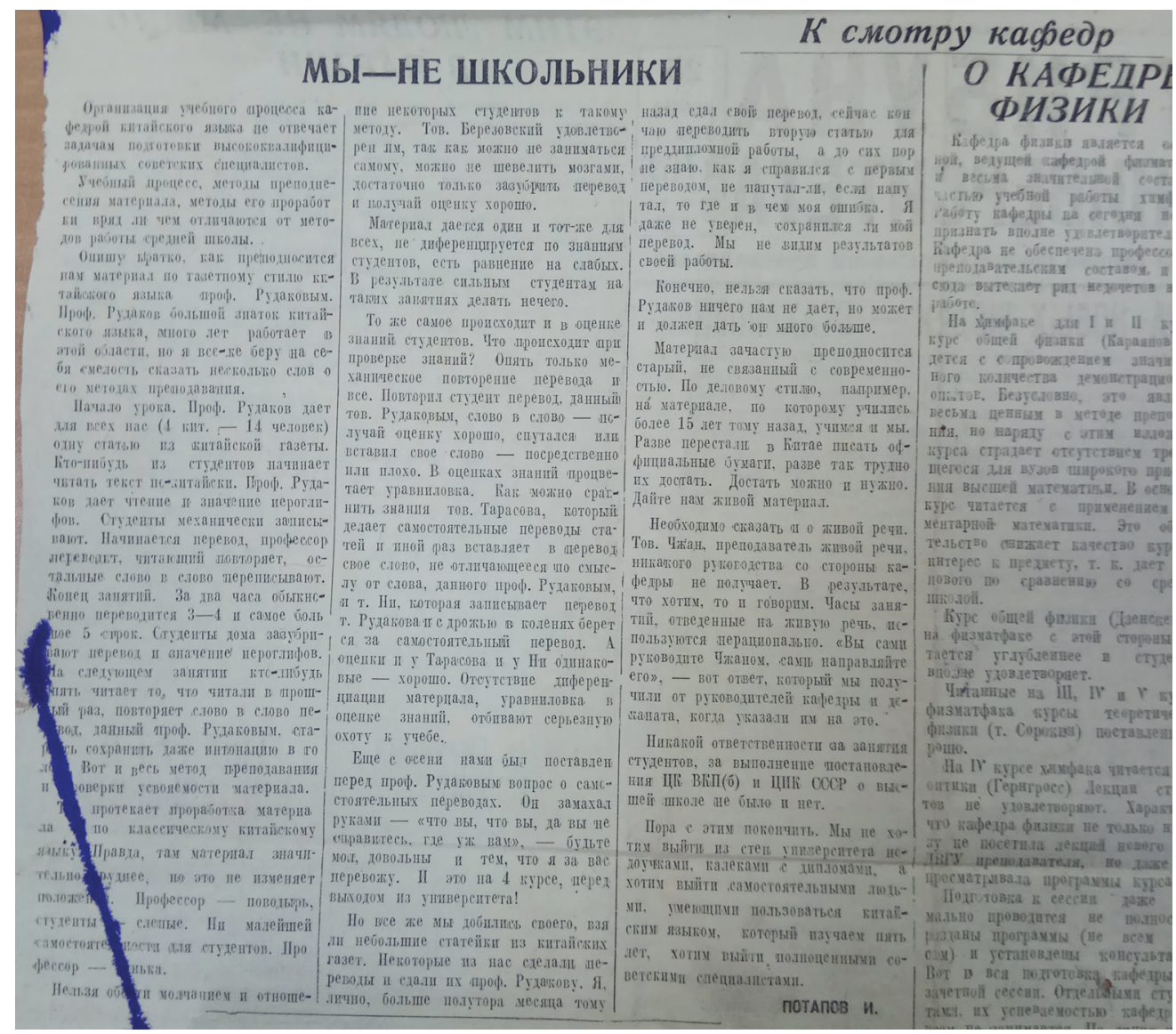

Рис. 1. Заметка И. Потапова «Мы не школьники» в газете «Трибуна университета» (№ 7 (19) от 25.12.1935), c. 2. Источник: РГИА ДВ Ф. Р-289. Оп. 1. Д. 291. Л. 1. читателю будничной: менялся стиль преподавания, несмотря на возвращение к более традиционным для высшей школы методам, нельзя было просто сдуть пыль со старых программ - требовался немалый труд для разработки курсов, соответствующих современным требованиям, опирающимся, что немаловажно, на марксистско-ленинскую методологию. Собственно, с последней у аполитичных востоковедов были наибольшие трудности, что и ставилось им в вину: несмотря на признание университетом заслуг А. В. Рудакова, его труды в это время уже не публиковались [2, с. 121-125; 6, с. 58]. Т. Д. Червонецкий, не принимавший новую идеологию, весной 1935 г. в течение месяца оставался уволенным как «реакционер» [2, с. 117-118].

Очевидно, что первая половина 30-х годов была очень беспокойным временем и для университета, и для его преподавателей. Одну из показательных ситуаций, раскрывающих атмосферу того времени, являет нам набор документов, хранящихся в Российском государственном историческом архиве Дальнего Востока, связанный с внутрифакультетской проверкой учебной деятельности сотрудников кафедры китаеведения, проводившейся в декабре 1935 - январе 1936 гг. Проверка была инициирована заметкой студента М. Потапова в университетской газете (рис. 1), в которой автор от лица студентов-ки- 


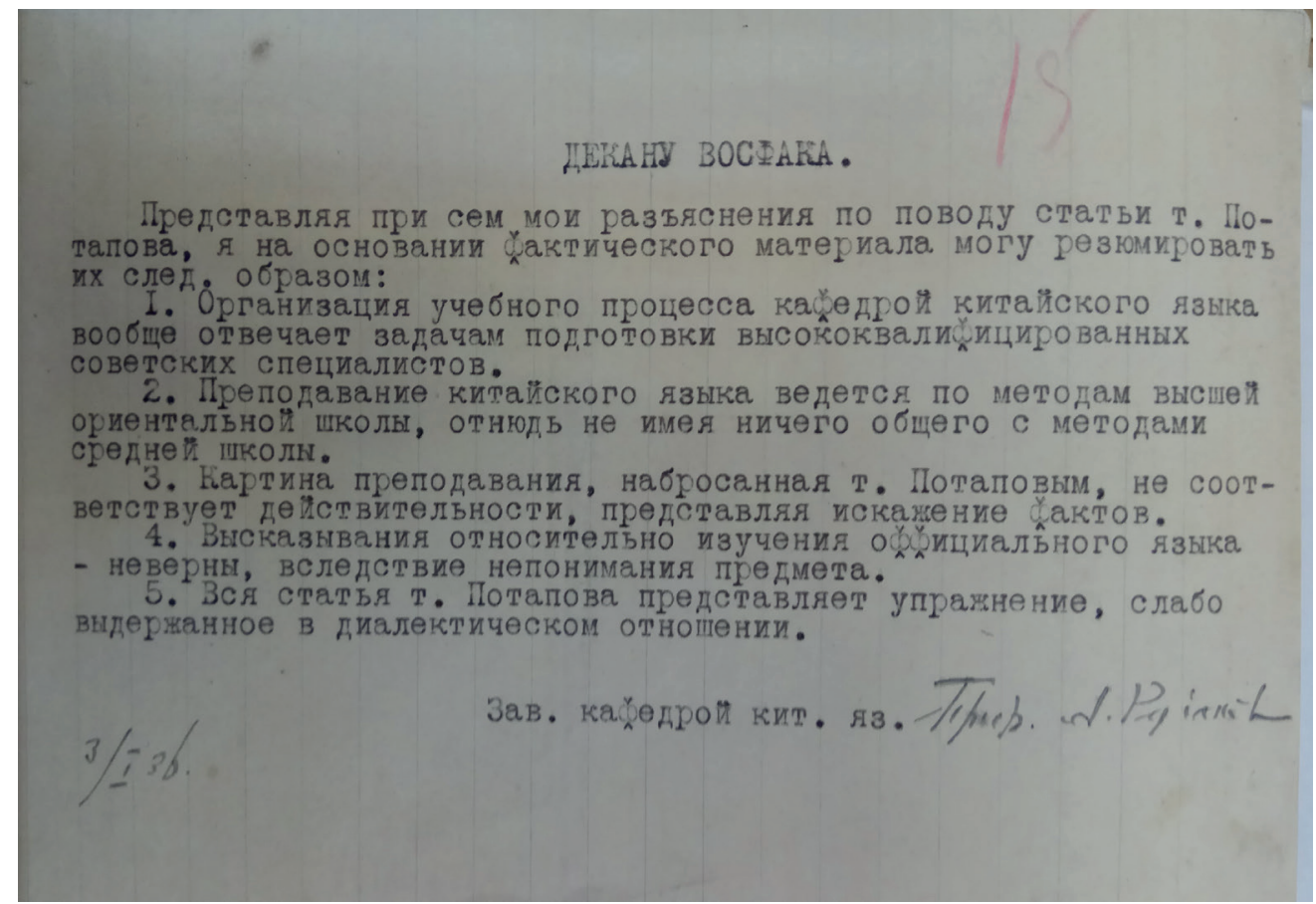

таистов, недовольных отказом от демократического бригадно-лабораторного метода, упрекает преподавателей (упоминаются Рудаков и Чжан) в деспотизме и формализме, уклонении от постановлений партии и правительства. В связи с этим заявлением администрация факультета организовала проверку работы кафедры китаеведения силами сотрудника кафедры японоведения К. П. Феклина и студенческого актива (Потапова и Денищенко). «Обследовательская бригада» представила несколько аналитических и обобщающих документов: материалы, выводы, практические предложения. В данных документах критике подверглась работа преподавателей А. В. Рудакова, Т. Д. Червонецкого, Чжан Юэ Жэня, в результате А. В. Рудаков (рис. 2) и Т. Д. Червонецкий (рис. 3) представили объяснительные записки администрации факультета и университета. Интересно, посещения занятий в рамках проверки кафедры (21 декабря) начинаются ещё до выхода заметки в газете (25 декабря). Как минимум можно предполагать, что публикации в газете предшествовала какая-то коммуникация между студентом Потаповым и администрацией факультета.

Чем ценны эти материалы? Пока данная история была внутренним делом университетской корпорации, разговор о принципах и методах образовательной и учебной работы вёлся на предметном уровне, позволяющем сегодня её реконструировать дать ей оценку. В материалах обследования подробно обсуждаются детали методик, способы использования учебных пособий, организация работы студентов и преподавателей. Вместе с тем на каждой странице бросается в глаза потенциал политизации образовательного конфликта, начи-
Рис. 2. Машинописная записка А. В. Рудакова (с автографом) декану Восточного факультета, 3.01.1936. Источник: РГИА ДВ Ф. Р-289. Оп. 1. Д. 291. Л. 15. 


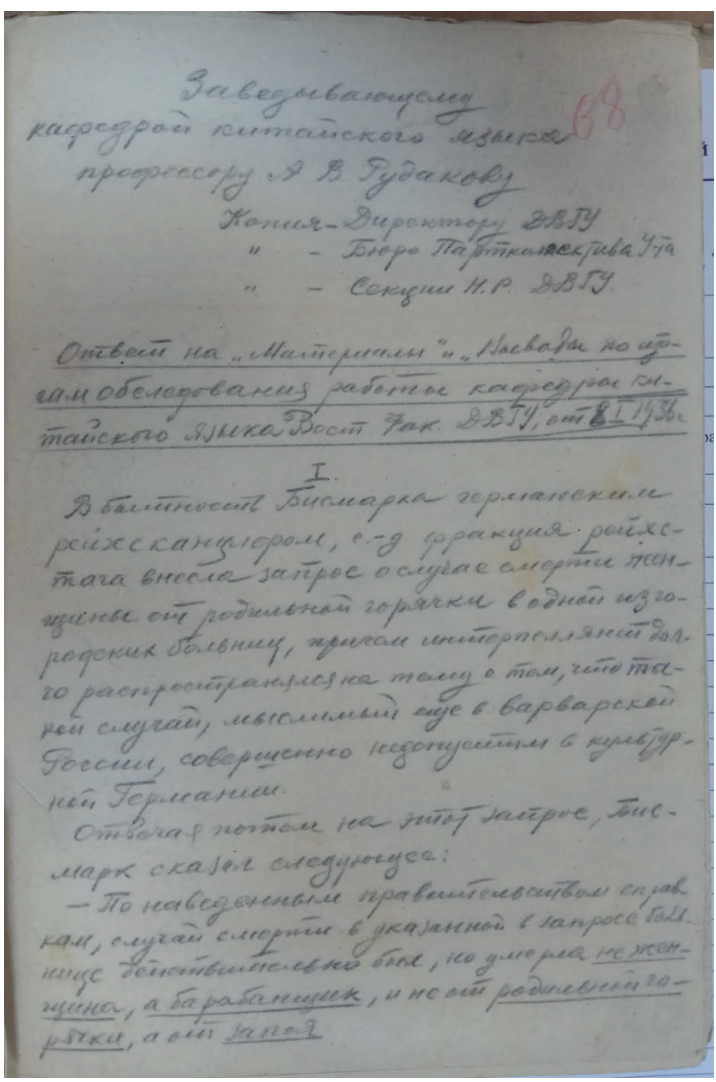

ная от упрёков студентов в неполноте получаемого ими, будущими советскими специалистами, образования и заканчивая оправданиями преподавателей за неучастие во внутриуниверситетских профессиональных соревнованиях. Окидывая взглядом эту картину, надо помнить о сгущающейся в течение 30-х гг. политической атмосфере СССР.

Собственно, репрессии второй половины 30-х в чём-то и разрешили этот конфликт; на уровне университета он был, похоже, замят. А. В. Рудаков, после разгрома и ликвидации университета в 1939 г. работал на курсах военных переводчиков ТОФ до смерти в 1949 г. [1, с. 73-74], Т. Д. Червонецкий в 1936 г. вернулся на малую родину в г. Изюм [5, с. 541], декан факультета В. А. Войлошников и К. П. Феклин были репрессированы и расстреляны во Владивостоке в 1938 г. [4, с. 101, 105], о судьбе студентов, принимавших участие в проверке кафедры китаеведения, информации нет.

Сюжет обследования деятельности кафедры китаеведения в

Рис. 3. Первая страница черновика объяснительной записки Т. Д. Червонецкого, 28.01.1936. Источник: РГИА ДВ Ф. Р-289. Оп. 1. Д. 291. Л. 68 крайне слабое освещение. Кратко этот конфликт упоминается в обзорной статье 1994 г. [6, с. 59]: Э. В. Ермакова и Е. А. Георгиевская дают общий очерк ситуации, делая больший акцент на политической, чем методической составляющей конфликта. В «Истории русского китаеведения» (2015) В. Г. Дацышен ещё более глухо упоминает о несогласии Рудакова с результатами оценки работы его кафедры [3, с. 221-222]. Очевидно, что исследовательский потенциал документов проверки 1935/36 гг. ещё далеко не раскрыт.

В Российском государственном историческом архиве Дальнего Востока в фонде «Дальневосточный государственный университет (1917-1939)» в составе дела «Материалы по итогам обследования кафедры китайского языка 1935-36 уч. год (31/XII-1935 г. - 28/I-1936 г.)» отложились следующие документы, представленные в нашей подборке: № 1, «Мы - не школьники!» (часть 1); № 2, «Материалы по итогам обследования работы кафедры китайского языка Восточного факультета Д. В. Г. У.» (часть 1); № 3, «Выводы по итогам обследования кафедры китайского языка Восточного факультета ДВГУ» (часть 2); № 4, «Предложения обследовательской бригады по итогам обследования работы кафедры Китайск. языка ВФ ДВГУ в 1935/36 акад. году» (часть 2); № 5, «Практические предложения» Производственного совещания 4 го курса китайского отделения Востфака (часть 2); № 6, предложения А. В. Рудакова в учебный отдел ДГУ по усовер- 
шенствованию учебного процесса (часть 2); № 7, докладная записка А. В. Рудакова декану Востфака (часть 2); № 8, «Критический обзор Материалов по итогам обследования работы кафедры китайского языка Восточного факультета Д. В. Г. У.» А. В. Рудакова (часть 3); №9, «К смотру кафедры китайского языка. 1936 г.» Т. Д. Червонецкого (часть 4). Часть 1 публикуется в данном выпуске журнала, части 2-4 будут опубликованы в соответствующих выпусках текущего года.

Представляемая читателю публикация не является первой: в связи с празднованием столетия университета уже были осуществлены две публикации: в 1999 году ДВГУ выпустил сборник документов (второе издание в 2004 г.), в который вошли заметка из «Трибуны университета» (рис. 1, документ № 1) документы № 2 и 7 [8, с. 515-536], из которых изъятыописания методических приёмов, содержание курсов и другие тонкие детали. Републикация документов № 2 и № 7 в том же составе, что и в 1999 м, была осуществлена Российским государственным историческим архивом Дальнего Востока в 2000 году [7, c. 99-118]. Таким образом, сегодня мы располагаем фрагментарным и далеко не полным отражением ситуации вокруг проверки кафедры китаеведения на рубеже 1935 и 1936 гг.; три существующих сегодня публикации восходят к одной редакции, сделанной сотрудниками РГИА ДВ в конце 90-х годов с целью дать общее (так сказать «юбилейное») представление о ситуации в университете середины $30-$ х годов. Это обстоятельство объясняет необходимость публикации как уже доступных, так и ещё не опубликованных документов, связанных с проверкой 1935/36 годов.

Знак «"» в тексте источника заменён на знак «ъ»; исправления, внесённые в текст сразу после его написания, включены в публикацию. Исправлены однозначные опечатки и изъяты избыточные знаки препинания. Сохранён авторский грамматический стиль и способ написания слов. По возможности сохранены элементы оформления документов. Все редакторские пометки и исправления помещены в квадратные скобки [ ]. Документы имеют перекрёстные ссылки, поэтому в части материалов проставлена оригинальная пагинация страниц в угловых скобках <> в месте начала каждой страницы, за исключением первой.

\section{Литература}

1. Врадий С. Ю. Профессор китаеведения А. В. Рудаков // Известия Восточного института Дальневост. гос. ун-та. 1999. № 5. С. 68-74.

2. Дальневосточный государственный университет. История и современность. 1899-1999 гг. / [Редкол. В. И. Курилов (гл. ред.), Э. В. Ермакова, Р. М. Самигулин]. Владивосток: Изд-во Дальневост. ун-та, 1999. 704 c.

3. Дацышен В. Г. История русского китаеведения 1917-1945 гг. М.: Издательство «Весь Мир», 2015. 352 с.
4. Донской В. К. Разгром Восточного факультета ДВГУ // Вестник ДВО РАН. 1996. № 1. С. 95-108.

5. Еланцева О. П., Ван Юе Тихон Дмитриевич Червонецкий - преподавателькитаист восточного факультета ДВГУ (1926-1936 гг.) // Россия и Китай: История и перспективы сотрудничества. Мат-лы VIII Междунар. науч.-практ. конф. Благовещенск: Изд-во Благов. гос. пед. ун-та, 2018. C. 537-542.

6. Ермакова Э. В., Георгиевская Е. А. Восточный факультет в 20-30 годы // Из- 
вестия Восточного института Дальневост. гос. ун-та. 1994. № 1. С. 52-63.

7. Из истории востоковедения на российском Дальнем Востоке. 1899-1937. Документы и материалы / Редакторы и сост. коммент. Н. А. Троицкая, А. А. Торопов. Владивосток: Прим. краев. орг-ция об-ва любителей кн., 2000. 256 с.

8. История Дальневосточного госу- дарственного университета в документах и материалах, 1899-1939 гг.: [сборник]

/ Дальневосточный государственный университет, Российский государственный исторический архив Дальнего Востока; [сост. О. В. Усталова и др.; ред. кол. В. И. Курилов (отв. ред.) и др.]. Владивосток: Изд-во Дальневосточного университета, 1999. 626 с.

\section{Yaroslav A. BARBENKO}

Ph. D. (in History), Assistant Professor, Department of Political Sciences, Oriental Institute - School of Regional and International Studies, Far Eastern Federal University (Vladivostok, Russia)

E-mail: prohist@ya.ru

\section{Materials of the Inspection of the Chinese Language Department of Far East State University, December 1935 - January 1936. Part 1}

In memory of Eleonora V. Ermakova and Olga P. Elantseva, who were the deedful researchers of the university's history

\section{DOI https://doi.org/10.24866/2542-1611/2021-1/89-113}

"Oriental Institute Journal" publishes a series of documents related to the dramatic pages in the history of the Far Eastern University and the Russian higher school as a whole. One of the indicative situations that reveal the atmosphere of that time is a set of documents stored in the Russian State Historical Archive of the Far East.

These are the documents related to the internal audit of the educational activities of the staff of the Department of Chinese Studies, conducted in December 1935 - January 1936. The audit was initiated by M. Potapov's note in the university newspaper (Fig. 1). The author, on behalf of Chinese-learning students, reproaches the teachers (Rudakov and Zhang are mentioned) for despotism and formalism, evading the decisions of the Communist Party and the Soviet Government. In response, the faculty administration organized an audit of the work of the Department of Chinese Studies, authorizing K. P. Feklin, an employee of the Department of Japanese Studies, and student activists (Potapov and Denishchenko). The "inspection team" presented several analytical and summarizing documents: materials, conclusions, and practical proposals. In these documents, the work of teachers A. V. Rudakov, T. D. Chervonetsky, and Zhang Yue Ren was criticized. As a result, A. V. Rudakov (Fig. 2) and T. D. Chervonetsky (Fig. 3) presented explanatory notes to the administration of the faculty and the university.

The publication of the entire series of documents is scheduled for four issues in 2021. 
For citation: Barbenko Y. A. Materials of the Inspection of the Chinese Language Department of Far East State University, December 1935 - January 1936. Part 1 // Oriental Institute Journal. 2021. № 1. P. 89-113. DOI https://doi.org/10.24866/2542-1611/2021-1/89-113

\section{References}

1. Vradij S. Yu. Professor kitaevedeniya A. V. Rudakov // Izvestiya Vostochnogo instituta Dal'nevost. gos. un-ta. 1999. № 5. S. $68-74$.

2. Dal'nevostochnyj gosudarstvennyj universitet. Istoriya i sovremennost'. 1899-1999 gg. / [Redkol. V. I. Kurilov (gl. red.), EH. V. Ermakova, R. M. Samigulin]. Vladivostok: Izd-vo Dal'nevost. un-ta, 1999. 704 s.

3. Datsyshen V. G. Istoriya russkogo kitaevedeniya 1917-1945 gg. M.: Izdatel'stvo «Ves' Mir», 2015. 352 s.

4. Donskoj V. K. Razgrom Vostochnogo fakul'teta DVGU // Vestnik DVO RAN. 1996. № 1. S. 95-108.

5. Elantseva O.P., Van YUe Tikhon Dmitrievich CHervonetskij - prepodavatel'kitaist vostochnogo fakul'teta DVGU (19261936 gg.) // Rossiya i Kitaj: Istoriya i perspektivy sotrudnichestva. Mat-ly VIII Mezhdunar. nauch.-prakt. konf. Blagoveshhensk: Izd-vo Blagov. gos. ped. un-ta, 2018. S. 537-542.

6. Ermakova Eh. V., Georgievskaya E. A. Vostochnyj fakul'tet v 20-30 gody // Izvestiya Vostochnogo instituta Dal'nevost. gos. un-ta. 1994. № 1. S. 52-63.

7. Iz istorii vostokovedeniya na rossijskom Dal'nem Vostoke. 1899-1937. Dokumenty i materialy / Redaktory i sost. komment. N. A. Troitskaya, A. A. Toropov. Vladivostok: Prim. kraev. org-tsiya ob-va lyubitelej kn., 2000. $256 \mathrm{~s}$.

8. Istoriya Dal'nevostochnogo gosudarstvennogo universiteta v dokumentakh i materialakh, 1899-1939 gg.: [sbornik] / Dal'nevostochnyj gosudarstvennyj universitet, Rossijskij gosudarstvennyj istoricheskij arkhiv Dal'nego Vostoka; [sost. O. V. Ustalova i dr.; red. kol. V. I. Kurilov (otv. red.) i dr.]. Vladivostok: Izd-vo Dal'nevostochnogo universiteta, 1999. $626 \mathrm{~s}$. 


\section{№ 1}

1 То есть 4 й курс китайского отделения - 14 человек (ред.).

\section{Мы - не школьники}

Организация учебного процесса кафедрой китайского языка не отвечает задачам подготовки высококвалифицированных советских специалистов.

Учебный процесс, методы преподнесения материала, методы его проработки вряд ли чем отличаются от методов работы средней школы.

Опишу кратко, как преподносится нам материал по газетному стилю китайского языка проф. Рудаковым. Проф. Рудаков большой знаток китайского языка, много лет работает в этой области, но я все же беру на себя смелость сказать несколько слов о его методах преподавания.

Начало урока. Проф. Рудаков дает для всех нас (4 кит. - 14 человек) ${ }^{1}$ одну статью из китайской газеты. Кто-нибудь из студентов начинает читать текст по-китайски. Проф. Рудаков дает чтение и значение иероглифов. Студенты механически записывают. Начинается перевод, профессор переводит, читающий повторяет, остальные слов в слово переписывают. Конец занятий. За два часа обыкновенно переводится 3-4 и самое большее 5 строк. Студенты дома зазубривают перевод и значение иероглифов. На следующем занятии кто-нибудь опять читает то, что читали в прошлый раз, повторяет слов в слово перевод, данный проф. Рудаковым, стараясь сохранить даже интонацию в голосе. Вот и весь метод преподавания и проверки усвояемости материала.

[Так же] протекает проработка материала [и] по классическому китайскому языку. Правда там материал значительно труднее, но это не изменяет положения. Профессор - поводырь, студенты - слепые. Ни малейшей самостоятельности для студентов. Профессор - нянька.

Нельзя обойти молчанием и отношение некоторых студентов к такому методу. Тов. Березовский удовлетворен им, так как можно не заниматься самому, можно не шевелить мозгами, достаточно только зазубрить перевод и получай оценку хорошо.

Материал дается один и тот-же для всех, не дифференцируется по знаниям студентов, есть равнение на слабых. В результате сильным студентам на таких занятиях делать нечего.

То же самое происходит и в оценке знаний студентов. Что происходит при проверке знаний? Опять только механическое повторение перевода и все. Повторил студент перевод, данный тов. Рудаковым, слов в слово - получай оценку хорошо, спутался или вставил новое слово - посредственно или плохо. В оценках знаний процветает уравниловка. Как можно сравнить знания тов. Тарасова, который делает самостоятельные переводы статей и иной раз вставляет в перевод свое слово, не отличающееся по смыслу от слова, данного проф. Рудаковым и т. Ни, которая записывает перевод т. Рудакова и с дрожью в коленях берется за самостоятельный перевод. А оценки и у Тарасова и у Ни одинаковые - хорошо. Отсутствие дифференциации материала, уравниловка в оценке знаний, отбивают серьезную охоту к учебе.

Еще с осени нами был поставлен перед проф. Рудаковым вопрос о самостоятельных переводах. Он замахал руками - «что вы, что вы, да 
вы не справитесь, где уж вам», - будьте, мол, довольны и тем, что я за вас перевожу. И это на 4 курсе, перед выходом из университета!

И все же мы добились своего, взяли небольшие статейки из китайских газет. Некоторые из нас сделали переводы и сдали их проф. Рудакову. Я, лично, больше полутора месяца тому назад сдал свой перевод, сейчас кончаю переводить вторую статью для преддипломной работы, а до сих пор не знаю, как я справился с первым переводом, не напутал-ли, если напутал, то где и в чем моя ошибка. Я даже не уверен, сохранился ли мой перевод. Мы не видим результатов своей работы.

Конечно, нельзя сказать, что проф. Рудаков ничего нам не дает, но может и должен дать он много больше.

Материал зачастую преподносится старый, не связанный с современностью. По деловому стилю, например, на материале, по которому учились более 15 лет тому назад, учимся и мы. Разве перестали в Китае писать оффициальные бумаги, разве так трудно их достать. Достать можно и нужно. Дайте нам живой материал.

Необходимо сказать и о живой речи. Тов. Чжан, преподаватель живой речи, никакого руководства со стороны кафедры не получает. В результате, что хотим, то и говорим. Часы занятий, отведенные на живую речь, используются нерационально. «Вы сами руководите Чжаном, сами направляйте его», - вот ответ, который мы получили от руководителей кафедры и деканата, когда указали им на это.

Никакой ответственности за занятия студентов, за выполнение постановления ЦК ВКП(б) и ЦИК СССР о высшей школе не было и нет.

Пора с этим покончить. Мы не хотим выйти из стен университета недоучками, калеками с дипломами, а хотим выйти самостоятельными людьми, умеющими пользоваться китайским языком, который изучаем пять лет, хотим выйти полноценными советскими специалистами.

Потапов М.

Мы - не школьники // Трибуна университета. 1935. № 7 (19). С. 2.

РГИА ДВ Ф. Р 289. Оп. 1. Д. 291. Л. 1.

№ 2

МАТЕРИАЛЫ

ПО ИТОГАМ ОБСЛЕДОВАНИЯ РАБОТЫ КАФЕДРЫ

КИТАЙСКОГО ЯЗЫКА ВОСТОЧНОГО ФАКУЛЬТЕТА Д. В. Г. У.

I. Наличие программ по отдельным языковым дисциплинам. Доведение программ и учебных планов до сведения студентов.

Среди дел секретаря Деканата Восточного Факультета нашлись лишь программы по следующим языковым разделам:

1. Программа по курсу кит. разговорн. языка для 1-го КУРСА. (Краткий перечень дозировки теоретического материала, распределения часов по отдельным методам, указание учебных пособий).

2. Программа по курсу латинизации кит. иероглифической письменности для 1-2 курсов (характеристику см. выше). 
3. Программа по курсу кит. разг. языка для 2-го КУРСА (характеристику см. выше).

4. Программа по курсу кит. разг. языка ДЛЯ 3-го КУРСА (см. выше: указана раскладка часов по разговорной практике и каллиграфии поручаемых преподавателю-китайцу).

5. Программа по курсу разговорно-литературного стиля (БАЙХУА) для 2-3 курсов (характеристику см. выше).

6. Учебная программа по китайскому газетно-журнальному стилю для 2, 3, 4 курсов (сводная записка, без хотя бы схематического пояснения номенклатуры даваемого грамматического материала).

7. Программа по кит. военной терминологии для 3-4 курсов (характеристику см. выше).

8. Учебная программа по основам литературного языка для 3-го курса. (Составлена более обстоятельно с некоторой детализацией содержания преподносимого материала).

9. Учебная программа по истории кит. литературы для 3-го курса (ошибочно написано «для 4-го курса»).

В программе уделяется очевидное преимущество памятникам древней классической литературы перед литературой нового и новейшего времени; о пролетарской литературе нет никаких упоминаний.

10. Учебная программа по классическому литературному языку для 4-го курса, по оффициальному и деловому стилю для 4-го курса) чрезвычайно сжатый материал - 9 строчек) и «по специальному семинарию на кит. языке» для 5-го курса (повидимому по современной кит. литературе и переводческому практикуму - проработка статей политического, финансового и экономического характера).

Кроме упомянутых 10-ти предельно сжатых программ по языковым разделам, у секретаря Деканата Восточного факультета еще имеется «Учебный план китайского отделения Восточного факультета ДВГУ», собственно говоря, раскладка часов по семестрам и за год по отдельным языковым и всем прочим дисциплинам без каких либо объяснительных записок к нему.

$<$ Стр. 2> На этом перечисление программных материалов кит. кафедры, имевшихся к моменту обследования в деканате Востфака, ограничивается.

Ни единого учебно-производственного плана кафедры, ни более развёрнутых календарных рабочих планов с конкретной детализацией материала в деканате не имелось.

При посещении профессора Рудакова научным работником кафедры японского яз. т. Феклиным 25-го декабря 1935 г. т. Рудаков показывал хранящиеся у него копии учебно-производственного плана и несколько рабочих планов, причем упоминал, что весь планово-программный материал был отправлен в учебную часть ДВГУ еще в конце прошлого акад. года. Тоже подтверждает с некоторым добавлением и доцент ЧЕРВОНЕЦКИЙ: все программы и рабочие планы были полностью сданы в конце прошлого ак. года в Учебную часть ДВГУ, там они были потеряны и пришлось возобновить лишь программы, дослав их снова уже в начале текущ. ак. года. Поэтому, говорит Червонецкий, я не могу сказать с точностью доведены ли полностью программы и учебные планы до каждого студента, но научные работники кафедры своевременно информируют студентов о предъявляющимся к ним требованиям к предстоящим зачетным сессиям. 
Студенческие представители по обследованию работы кафедры в результате опроса студентов 4-х курсов констатировали, что имеющиеся программы доведены до сведения всех студентов. В большей части программ не указана совершенно целевая установка данного курса. Имеются примеры, когда программы не дифференцируются по курсам: на 2 и 3 курсах по курсу …….............................. прорабатывается одна и та же брошюра Мартынова «Тянь цзянь ды-шу-цзы-дуйюань». На 3-4 курсах прорабатываются одни и те же оффициальные бумаги по устаревшему учебнику Отто.

Серьезным отрицательным моментом в программах учебного процесса кафедры (правда, недостатком, так сказать, хронического характера, благоприобретенного Советским Востфаком ДВГУ по традиции от дореволюционного Восточного Института) является полное игнорирование ими работы преподавателя-национала по разговорной практике и письму. Никаких методических указаний или хотя бы наметок преподавателю-китайцу не дается. Ни о какой программе живой речи и письма нет нигде ни одного слова (за исключением голой разнарядки поручаемых ему часов в оной лишь программе). Таким образом, преподаватель, в полном смысле слова, предоставлен всецело собственной инициативе, долженствующей одиноко плыть по воле стихии общей педагогической работы кафедры.

Наличие только лишь учебных программ в том виде, как застало их обследование в деканате, без календарных детальных планов, явно не удовлетворительно. Так, например, в программе по разговорно-литературному стилю для 2-3 курсов (доц. Червонецкий) совершенно не указан конкретно проходимый материал. Курьезно выглядит фраза в программе спец.-семинара на кит. языке для 5-го курса - «приобретение навыков в пользовании словарями на китайском языке». Можно было-бы, думается, преподать эти навыки исподволь и с 3-4 курсов.

\section{2. Соотношение лекций к семинарам. Качество лекций и семина-} ров.

По мнению председателя кафедры проф. РУДАКОВА, налицо полное гармоническое сочетание между лекциями и семинарами. Соотношение часов уделяемых преподавателям русским и китайцу также не оставляет желать ничего лучшего. Добавления доц. ЧЕРВОНЕЦКОГО: <стр. 3> лекций, как таковых, проводится очень мало, по преимуществу они вводного характера. Кафедра неуклонно стремится держать качество их на должной высоте.

Студенческий представитель обследования на 3-4 курсах констатирует, что «\% соотношения лекций таких, какими они должны быть, нет. Есть только семинары. УВЯЗКИ ТЕОРИИ С ПРАКТИКОЙ НИКАКОЙ». Очевидно, речь идет о бессистемной работе преподавателякитайца по разговорной практике. В отношении качества лекций и семинаров следует, прежде всего, упомянуть результаты обследования студенческого представителя по состоянию лекций и семинаров на 1-2 курсах: «Преподавание теории разговорного языка (доц. ЧЕРВОНЕЦКИЙ) проходит нормально». Недостатком работы кафедры нужно считать слабое руководство и контроль над работой преподавателя разговорной практики тов. ЧЖАН-ЮЭ-ЖЕНЬ. Студенты на некоторую бессистемность в его преподавании и отсутствие подготовки к урокам, в результате чего на уроках живой речи не закрепляется язы- 
ковой материал, полученный по теории разговорного языка. Причем в проработке участвуют лишь наиболее активные студенты. Остальная же часть отмалчивается и т. ЧЖАН не привлекает их к участию. Дозировка времени для объяснений свежего материала и опроса, по мнению студентов, вполне нормальна.

На 2-м КУРСЕ... времени для проработки и усвоения нового материала отводится недостаточно. В течение шестидневки студент получает 80-110 новых иероглифов (Теория разгов. языка: 10-30 знаков, Газетный стиль - не менее 40 знаков, Литературный стиль - не менее 40 знаков). Студенты жалуются на поверхностность проработки, особенно по газетному стилю, материал разобранный на предыдущем занятии, как правило, на следующем занятии не повторяется. Поскольку же весь материал разбирается на уроке без предварительной подготовки со стороны самого студента, результаты такой однократной проработки весьма не высоки.

Уроки разговорной практики не закрепляют полученного материала, т. к. ведутся на темы, не связанные с прорабатываемым теоретическим материалом и сопровождаются тщательной подготовкой самого преподавателя-китайца.

Далее, приводим результаты обследования студенческим представителем занятий по теории разговорного языка НА 3-М КУРСЕ, а также по газетному стилю и классическому языку НА 4-М КУРСЕ: «Все они носят ярко выраженный отрицательный характер. Метод преподавания на этих курсах не только не приучает студентов к самостоятельной работе, но, наоборот, заглушает проявление всякой самостоятельности в учебе.

Например, проработка общих (для всех студентов одинаковых) статей состоит по существу в подаче перевода самим профессором, причем никакого внимания не обращается на грамматический разбор фраз. Нет дифференцированного подхода к каждому студенту в отдельности. При опросе студентов 3-4 курсов я не нашел положительных сторон в работе кафедры. Повсюду скользит безответственное отношение к делу подготовки действительных специалистов китайского языка».

Студенческий представитель по обследованию работы кафедры НА 5-М КУРСЕ говорит следующее: «Необходимо обратить внимание на постановку преподавания курса истории китайской литературы, читаемого проф. РУДАКОВЫМ. История китайской литературы излагается вне всякой связи с социальной основой и с социальными сдвигами, имеющими <стр. 4> место в Китае. Трактовка вопросов литературной революции буржуазными синологами предлагается студентам без каких нибудь критических замечаний, как истина в окончательной инстанции. Программа этого курса до студентов не доведена и вообще вызывает сомнение вопрос, есть-ли таковая программа.

Курс методики преподавания кит. языка также требует пересмотра. При всей полезности (обзор недостатков преподавания кит. языка на Востфаке ДВГУ) постановки вопроса, он, повидимому, рассчитан на подготовку преподавателя высшей школы, тогда как целеустановка нашего Востфака - подготовка преподавательских кадров для средних школ Края. Специфике преподавания кит. языка среднешкольникам не уделяется никакого внимания. 
Далее НА 5-М КУРСЕ отведено 30 часов изучению скорописи под руководством китайца-преподавателя, т. ЧЖАН. Курс проходит вяло. Основные причины этого: слабая домашняя подготовка самих студентов и некоторая бессистемность в преподавании т. ЧЖАН. Иногда дается материал случайного характера. Закрепление материала далеко не достаточное.

СПЕЦТЕРМИНОЛОГИЯ на 5-м курсе, т. е. Самостоятельный перевод на русский язык переводной брошюры доклада т. Сталина на XVII съезде партии. Курс поручен профессору РУДАКОВУ, однако переводы студентов еще ни разу не подвергались его проверке».

В заключение, при подведении итогов обследования работы кафедры по данному разделу, помещаем материал личного обследования научным работником т. ФЕКЛИНЫМ ведений лекций и практических семинаров на 4-х курсах кафедры.

21-ГО ДЕКАБРЯ 1935 г. 1-й КУРС; Теория разговорного языка (доц. ЧЕРВОНЕЦКИЙ). Группа 10 человек.

Как ПОЛОЖИТЕЛЬНЫЕ стороны следует отметить хорошую дисциплину группы, аккуратные записи в тетрадях. Преподаватель вел занятие по устному обратному переводу.

ОТРИЦАТЕЛЬНОЕ: Преподаватель слишком много дидактически разглагольствует с аудиторией, ведя беседу в форме выговоров, зачастую слишком в утрировано-патетической манере. Частые его дидактические сентенции разрывают нить педагогического процесca, будоражат необходимое для рабочего средоточия настроение и, несомненно, расхолаживают студентов. Со стороны преподавателя подбор задаваемых студентом фраз для обратного перевода идет несколько вялым темпом. Обильное изливание в глубокопессеместическом тоне порицающих сентенций, несомненно, уже стало привычным для ушей аудитории, воспринимается ею иронически и, конечно, содействует лишь расхолаживанию рабочего настроения. Опрос студентов не ровен. Слабые не удостаиваются внимания преподавателя. В результате длительных опросов к концу урока из 10-ти студентов двое не опрошено совсем.

Группа оставляет впечатление крайне пассивной аудитории. Несомненно, немалую способствующую роль здесь в понижении тонуса рабочего настроения играет описанный выше метод преподавателя воздействия на студентов: если успевающие и проявляют хоть ничтожную активность в самостоятельном составлении разговорных фраз под градом сыплющихся упреков о ничегонеделании, то отстающие студенты обречены почти на полное пассивное слушание заведомо не располагающих их к активной работе над языком отношением к ним преподавателя.

В изучении языка для целей активного пользования им такой подход к аудитории не может дать высоких результатов. Опрашивая студентов, преподаватель не ставит отметок по их отчетам, следовательно, кривая роста успехов студента в учебе и его сознательности <стр. 5> к работе останется незафиксированной, это лишь способствует уравниловке и не стимулирует отстающих.

23-ГО ДЕКАБРЯ 1935 Г. Разговорная практика. Лектор ЧЖАН. Урок каллиграфии. В общем студенты пишут вполне удовлетворительно, но отдельные детали иероглифов, написанные не в китайской манере, преподавателем не исправляются. Иными словами, студен- 
там не прививается систематически и исподволь основа истинно каллиграфического почерка иероглифов. Малоэффективным приемом нужно признать задавание здесь у доски 2-м студентам одной и той же фразы. Далее проводится урок разговорной практики. Здесь нельзя не отметить, как положительную сторону качества личности лектора, т. ЧЖАН. Основным ценным качеством его работы, особенно важным в его роли является живой, активный темперамент, воля и несомненное желание к работе и хорошая дикция. Эти качества делают его, при наличии у него соответствующего, хоть и не высокого образования чрезвычайно ценным для кафедры работником, могущим дать при надлежащей планомерной постановке его работы блестящие результаты. К сказанному следует добавить безупречно корректное отношение его к аудитории, встречающее, к сожалению, со стороны отстающих студентов порой далеко не тактичный прием в форме упорных отмалчиваний на задаваемые им лектором вопросы.

Но и на уроках т. ЧЖАН следует отметить недостатки общего характера: разговор преподавателя ведется только лишь с передовыми студентами, преимущественно с 1-2 корейцами. Остальные остаются немыми слушателями ведущихся диалогов. Наиболее отстающие сидят на задних партах и даже не пытаются проявить какую-либо активность. Определенной тематики для бесед, очевидно, не имеется. Лектор сам в процессе работы измышляет материал для вопросов. Отметок также никаких не ставится. Много студентов, а среди них и все слабые, остаются не опрошенными и сидят в пассивном бездействии весь урок. Урок проходит вяло, несмотря на наличие у лектора всех необходимых для активации качеств.

21-го ДЕКАБРЯ. 2-Й КУРС. Теория разговорного языка (доц. ЧЕРВОНЕЦКИЙ). Опрос устного перевода заданного текста. Следует отметить, как ПОЛОЖИТЕЛЬНУЮ сторону, аккуратное ведение записей студентами, общий удовлетворительный почерк записываемого иероглифического текста. Дисциплина хорошая. Аудитория, по видимому, имеет все возможности работать активно над языком. Здоровые отношения к работе. Но все эти хорошие качества принимают общий фон глубочайшей пассивности при работе под руководством преподавателя. Его метод взаимоотношений с аудиторией отличается теми же качествами, которые упомянуты нами при описании ведения семинар на 1-м курсе (см. выше). Нервирующий тон преподавателя создает неспокойную рабочую обстановку. Процесс его разрывается спорами студентов с преподавателем, напр., по моментам произношения. Опрос аудитории неравномерен: некоторые студенты опрашиваются по 3 раза, другие - ни одного. Отметок по опросу никаких не ставится.

21-го ДЕКАБРЯ. 2-й КУРС. Разговорная практика. Лектор т. ЧЖАН. ПОЛОЖИТЕЛЬНЫЕ стороны: Лектор вполне активен. Речь его хорошей дикции и идет беспрерывно. По-русски почти совершенно не говорит. Незнакомые термины пишет на доске четкой иероглификой. Аудитория тепло встречает лектора. Ответы довольно живы.

К ОТРИЦАТЕЛЬНЫМ сторонам нужно отнести следующие моменты: отсутствие стержневой тематики. Бессистемные вызовы студентов. Лектор говорит больше сам. Пока опрашивается один студент 6-8 минут, остальные занимаются «своими делами». Зачастую отве- 
чают хором <стр. 6> без вызова лектора. Сидящие на задних партах вяло участвуют в работе. Разговор ведется лишь в форме вопросовответов. Повествовательный вариант не используется. В результате в разговоре участвуют лишь 2-3 активных студента, остальные крайне пассивны. Нет индивидуального подхода к студентам. Отметок не ставится. Из 16-ти человек за 1 ак. час спрошено 8. Несмотря на вполне нормальные взаимоотношения лектора и студентов аудитория крайне пассивна.

30 ДЕКАБРЯ. 3-й КУРС. Теория разговорного языка (доц. ЧЕРВОНЕЦКИЙ). Аудитория 5 человек. Опрос перевода заданного текста. Следует отметить общий, повидимому, для всех курсов выше нами описанный тон преподавателя в обращении к студентам. Все те же непрерывные выговоры глубокопессеместического характера, изобилующие выражениями вроде «сбрендили форменным образом», обескураживающие даже не робких студентов, не говоря уже об отстающих. В итоге - всеобщее вялое нерабочее настроение, слабые переводы, отсутствие заинтересованности студентов к проходимому материалу. Никаких оценок по ответам студентов не делается.

25-го ДЕКАБРЯ. 4-й КУРС. Газетно-журнальный стиль. Ведет профессор Рудаков. Проводится краткое предзачетное совещание. Студенты просят профессора дать, кроме заученного материала к зачетной сессии по примеру японской кафедры, свежие газетные заметки индивидуально каждому студенту. Профессор соглашается. Идет опрос заданного материала - перевод общей (переписанной под копировальную бумагу) статьи. Профессор вдумчиво и крайне корректно подходит к ответу студента. Делается обстоятельный разбор синтаксического порядка с дословным переводом текста. Заметна излишняя медлительность и повторяемость в переводной работе, досаждающая более успевающим студентам. Обработанного (литературного) перевода не делается, в результате в переводе царит своеобразный жаргон незвучащих по русски выражений. Оценок по ответам студентов не ставится. Как выясняется, опрашиваемый перевод не делается самостоятельно студентами, а записывается ими со слов профессора и неукоснительно заучивается наизусть. Так же, по словам студентов, проходит работа и по изучению классической литературы кит. языка. Студенты механически записывают иероглифику и даваемый профессором перевод и отвечают его, заучив наизусть. Никаких методов по внедрению навыков самостоятельной работы не применяется. Широко практикуемая на кафедре японского языка со 2-го курса самостоятельная работа студентов над переводами газетных вырезок не имеет совершенно места на кафедре кит. языка. Подобный метод «зазубривания» предлагаемого перевода чрезвычайно вреден, т. к. замораживает в самом начале мозговую работу учащегося в данной области.

По отзыву студенческого представителя 4-го курса, преподаватель разговорной практики т. ЧЖАН «никакого руководства со стороны кафедры не получает. Часы отведенные на живую речь, используются нерационально. «Вы сами руководите т. Чжаном, сами направляйте его» - вот ответ, полученный студентами от руководителя кафедры и деканата. В результате разговор на урках ведется совершенно бессистемно, вяло и неинтересно. 
25-го ДЕКАБРЯ. 5-й КУРС. Литературная революция в Китае. Лекции проф. Рудакова. По содержанию этих лекций исчерпывающие данные помещены нами выше, см. мнение студ. представителя по обследованию работы кафедры на 5-м курсе. <стр. 7> Соглашаясь полностью с мнением представителя, заметим, что взамен таких лекций для студентов несравненно полезнее было бы прослушать сжатый, но систематизированный курс истории кит. литературы с древнейшего периода до современного с обязательной увязкой чередования литературных эпох с градациями социально-экономического уклада жизни Китая (а, следовательно, и ступенями переустройства государственно-политического строя). Такой курс с обязательной демонстрацией (читкой) важнейших литературных произведений в русском переводе был бы весьма кстати для расширения кругозора будущих дипломантов. Затем крайне важно дать в сжатом очерке (не более 4-х лекц. часов) историю возникновения и современное положение пролетарской литературы Китая. На кафедре японского языка оба эти момента учтены и проводятся в жизнь на занятиях 5-го курса.

Заканчивая второй раздел нашего обследования, мы должны сказать еще несколько слов о курсе латинизации китайской иероглифической письменности.

Проф. РУДАКОВ отмечал при обследовании, что этот курс, несмотря на наличие программы, фактически теперь не проводится за неимением преподавателя-специалиста. Единственный путь практического ознакомления с латинизацией - латинизированная транскрипция иероглифики, помещаемой в учебнике разговорного языка.

Доц. ЧЕРВОНЕЦКИЙ высказывает сое мнение о невозможности современного кит. языка. Находит, что сам по себе процесс латинизирования кит. текста очень легко воспринимается учащимися, знакомым с английским языком, отсюда не видит острой необходимости в преподавании специального курса латинизации. Однако, утверждает, что преподавание латинизации будет введено со 2-го семестра на 1-м курсе.

СТУДЕНЧЕСКИЕ ПРЕДСТАВИТЕЛИ отмечают полное отсутствие преподавания латинизации на всех курсах.

3. Различие в методе преподавания на младших и старших курсах. Проф. РУДАКОВ. На старших курсах применяется несколько иная методика: уделяется больше внимания самостоятельной активной проработке студентов.

Доц. ЧЕРВОНЕЦКИЙ. При единой методике на старших курсах предоставляется все более место самостоятельной работе студентов. 1-й КУРС - исключительно лишь воспринимает влияние преподавателя. Возможности самостоятельной работы весьма ограничены, но и здесь даются регулярные самостоятельные письменные работы - короткие сочинения на заданные и свободные темы. 2-й КУРС - большее внимание самостоятельной работе - навыки работы со словарем, самостоятельный разбор текста, дача неразделенного текста для расстановки студентами соответствующей пунктуации. Работа с разноязычными словарями (русские и английские). С 1-го курса студент приучается к способу выражать свои мысли на кит. языке в пределах имеющегося лексикона. Упражнения в обратном переводе с новыми лексическими <стр. 8> комбинациями для приучивания студентов к 
догадливости при переводе незнакомых конструкций. Объяснение преподавателем незнакомых слов описательным путем. 3-й КУРС все упомянутые приемы применяются еще шире. Заканчивается теория разговорного языка. Подводятся итоги теоретических познаний. Против слов политической и бытовой сферы 1-2 курсов на 3-м курсе - преобладание политик-экономической лексики (проходятся специальные тексты).

ПИСЬМО - большое внимание уделяется каллиграфии, ибо без знания иероглифики немыслимо знание слов. 1-2 курсы - ведутся диктанты и упражнения в письменном переводе с русского на китайский язык. 3-й курс - диктантов нет, преобладает форма письменного изложения на заданные темы.

СТУДЕНЧЕСКИЙ ПРЕДСТАВИТЕЛЬ По обследованИю 1-2 курсов отмечает следующее: самостоятельная работа студентов на 2-м курсе сводится лишь к подъискиванию новых иероглифов к каждому уроку по теории разговорного языка. Отсутствие какой-либо самостоятельности в проработке газетного материала на 2-курсе вызывает всеобщее недовольство студентов.

4. Форма работы с отстающими студентами. Форма, метод и частота проводимых консультаций

Представители кафедры тт. РУДАКОВ и ЧЕРВОНЕЦКИЙ: На лекциях непосредственно обращается внимание на отстающих, их более часто подвергают спрашиванию. Дается повторительный опрос материала для слабых. Существуют буксиры. Заседания кафедры систематически посвящают отстающим особое внимание, как кардинальному вопросу. Помощь отстающим не «компанейского» характера, а во внимательном отношении к ним на занятиях с начала года.

Консультации на 1-2 курсах - повторение обычного семинара, на 3-4 курсах - помощь в отношении преддипломных работ: студент прочитывает сделанный перевод текста по частям, перевод подвергается исправлениям и выяснениям слабых мест. Здесь уделяется серьезное внимание самостоятельной работе. На консультации 3-4 курсов уделяется согласно инструкции $10 \%$ лекционного времени специально во второй день шестидневки. Консультация на 1-2 курcax состоит не только в повторении материала и ответах на вопросы, но и со стороны преподавателя даются наводящие вопросы, требующие ответа (теория разгов. языка). Кроме положенных инструкцией часов консультаций 1-2 курсов, преподаватель (т. Червонецкий) дает добровольно консультационные часы после лекционных («седьмые» часы), не оплачиваемые учебной частью. Производится со стороны преподавателя и через треугольник Университета всемерный нажим против нежелающих работать студентов-лодырей.

МНЕНИЕ СТУД. ПРЕДСТАВИТЕЛЕЙ: Работа с отстающимИ студентами кафедрой почти не ведется. Отстающим уделяется недостаточно внимания т.т. Червонецким и Чжаном. Отстающим помогают сами студенты. Введение консультационных часов, согласно инструкции Наркомпроса, должно, думается, поставить этот вопрос в нормальное положение. Пока было проведено всего <стр. 9> несколько консультаций. На 3-4 курсах консультации превращены в опрос и проводятся крайне редко без всякого плана. 
В заключение, принимая во внимание резкое расхождение мнений сторон представителей кафедры и студ. представителей по данному вопросу, позволим себе сказать, что материал, полученный от представителей кафедры по меньшей мере страдает некоторыми фактическими неточностями: нами лично замечено, что никакой помощи отстающим студентам 1-2 курса на лекциях не делается: на уроках теории они сидят в крайне забитом состоянии, а на разговорной практике также лектор мало уделяет внимания, разговаривая с более успевающими.

5. Степень обеспеченности учебниками, дополнительная литература, иностранная (специальная) литература.

Проф. РУДАКОВ. Студенты обеспечены учебниками не вполне. В настоящее время доц. Червонецкий ведет работу по составлению учебника по военной терминологии. Т. т. Рудаков и Чжан заняты составлением 2-й части учебника кит. разг. языка. Работа идет весьма успешно, сдать к печати предполагается к середине января. По классическому литературному языку дается некоторая дополнительная литература. Специального ознакомления с иностранной литературой не ведется. Частично это мотивируется плохим знанием студентов в области английского языка и незнанием других языков, это, действительно, слабые места кафедры.

Доц. ЧЕРВОНЕЦКИЙ. 1-й курс полностью снабжен учебником разговорного языка. Текущий материал для письменных работ, диктантов и т. д. составляю сам; на 2-м курсе учебные тексты размножаются переписниками, а также переписываются самим студентами в свои тетради.; на 3-м курсе желательно было бы иметь иностранные учебники (кит. текст с переводом на англ. Язык), но кафедра ничего не получает. Используемая здесь в качестве пособия брошюра - перевод речи т. Молотова представляет работу южанина, поэтому нам, изучающим северный диалект кит. языка, приходится переделывать места диалектических [диалектных] расхождений. Желательно приобретение более подходящего пособия.

СТУД. ПРЕДСТАВИТЕЛИ. Учебные пособия имеются не на всех курсах. Нехватает словарей. Дополнительная литература на русском и иноязыках, как правило, отсутствует и кафедрой не рекомендуется. Отсутствие пособия по газетному стилю восполняется размножением текстов, которое вполне удовлетворяет студенческие нужды. Необходимо отметить, что переписывание студентами 2-го курса учебного текста с листков (учебника нет) хотя и сопряжено с каллиграфической практикой, но отнимает много рабочего времени у студентов. Курс литературного стиля ведется по повести Мартынова «Ударники полей» (на кит. языке). Текст этот очень труден для студентов 2-го курса, большие дозы новой иероглифики. Студенты ставили перед деканом вопрос о необходимости замены этого пособия, но безрезультатно.

<стр. 10> 6. Успеваемость групп по дисциплинам. Причины отставания в группах и работе кафедры по направлению выявления причин отставания

Доц. Червонецкий: 1-й и 2-й курсы представляют из себя каждый в отдельности две резко отличающиеся по уровню успеваемости группы: 1. отличники и 2. чрезвычайно пассивный элемент и лентяи (Тур 1 к., Хренов - 2 к.). Есть неподготовленные совершенно студенты, 
напр. Шемякин (1 к.), Плюснин (2-й курс). 3-й курс, за исключением одного студента, совершенно безнадежные люди. Вообще большинство товарище работает слабо и не слушается руководящих указаний преподавателя. Это - тяжелая сторона нашей работы. На заседаниях кафедры обсуждаются индивидуальные оценки, разбирается характер неуспеваемости с указанием ее причин. Обычно со стороны студентов даются обещания подтянуться, но тем не менее к зачетной сессИИ МЫ ПрИХОдИМ ЧРЕЗВЫЧАЙНО НЕУВЕРЕННЫМИ В СЕБЕ. Для выправления положения веду систематическое повторение всего пройденного. Обязываю к ведению записей по теории языка. Кафедра старается действовать на нежелающих работать студентов через треугольник Университета.

Проф. Рудаков. На 4-м курсе наблюдается за последнее время некоторый подъем. Средние оценки по газетно-литературному стилю дают: отл. 1, хор. 6, плохо. 1, остальные посредственно. На 3-м курсе: отл. 1, хор. 2, посред. 5, плохо 1. На 5-м курсе: также наблюдается некоторый поъем по успеваемости сравнительно с началом года: Денищенко - отл, Найдюкова, Пинчук, Гурьев, Желтоножко - посред., Назаров - хор.

Причиной отставания прежде всего служит сильное запаздывание студентов к началу учебного года, затем следует отметить распущенность и халатность в отношении к занятиям, наблюдающуюся на 3-м курсе (факты отмечены статьей в «Трибуне Ун-та»)1․ В начале ак. года третьекурсники искуссно маскировали ответы по «шпаргалкам», затем, когда были уличены, то успеваемость ответов резко упала. Только теперь начинает изживаться несознательное отношение к учебе. С неуспевающими студентами кафедра работает непосредственно во время лекций, за ними ведется постоянное наблюдение и оказывается особое внимание. В этом отношении кафедрой сделано очень много. Вопрос успеваемости студентов разбирается весьма тщательно на всех заседаниях кафедры.

СТУД. ПРЕДСТАВИТЕЛИ. ПричИнЫ отставаниЙ, кроме личных (к студенту относящихся), заключаются в плохой постановке учебного процесса (не дифференциации материала по способностям студентов, доминирует метод пассивного восприятия и т. д.). У отдельных преподавателей установилось мнение в отношении некоторых студентов, как безнадежных, ввиду чего этим студентам ставится оценка «плохо» как-бы по привычке, так сказать «по традиции». Никакой работы кафедра с отстающими студентами не ведет.

Далее помещаем выдержки из доклада доц. ЧЕРВОНЕЦКОГО на заседании Деканата Востфака 20-го декабря о состоянии подготовки кафедры к зачетной сессии:

«На 2-м курсе программ количественно проходит нормально. Имеется угроза к благополучному выполнению со стороны отношения студентов к работе. На 1-м курсе успевают вполне студенты-корейцы. Второгодники также не отстают, за исключением безнадежного_<стр. 11> т. Шемякина. Особенно безнадежен из русских студент Тур. На курсе имеются две студентки нервического типа (Кириллова и Степаненко), которые едва поспевают за средними студентами. Все консультации идут за счет активности самого преподавателя. Студенты пассивны. Качество проработки ими материала низкое. За последнее время намечается некоторый сдвиг - вся группа занима-
${ }^{1}$ См. документ № 1 (ред.). 
ется бригадой под руководством однокурсника т. Хан. Единственное светлое явление в работе курса - студент Вяткин, который поступил в Университет значительно позднее всех, но теперь идет уже впереди всех студентов курса.

2-й курс - небольшая группа занимается хорошо, остальные совершенно расхлябались. Многие безнадежно отстают. Беседы преподавателя со студентами не приводят ни к чему.

3-й курс. Очень слабы: Карловский и Хан.

4-й курс. Уровень успеваемости не идет выше посредственных отметок. У студентов нет интереса к своей работе. Характерно, что 3-4 курсники приходят на консультации, а младшекурсники - нет. Среди студентов ВООБЩЕ КАКОЕ-ТО УНЫЛОЕ НАСТРОЕНИЕ».

В заключение позволим себе сказать насколько слов по поводу столь разноречивых материалов по данному разделу обследования:

Мы склонны думать, что именно формальное отношение самой кафедры к студенческой массе породило то, что, по выражению тов. Червонецкого, «мы подходим к зачетной сессии чрезвычайно неуверенными в себе». Постоянно брюзгливый тон бесед этого преподавателя и является по всей вероятности главной причиной «упаднического настроения». Трактовка же преподавателя о «безнадежных студентах» устарелая фикция, нуждающаяся в должном отпоре. «Безнадежные студенты» в среде нормально развитых, здоровых юношей и девушек это - достойный осмеяния абсурд. Это или лодырь, за которого нужно крепко и умело взяться, или же оставленный на произвол судьбы отстающий студент. Оба варианта в нашей студ. жизни вполне возможны и оба они могут быть превращены в хотя бы посредственных студентов в короткий срок.

7. Изучение кафедрой системы и методов работы студентов и передача опыта работы передовиков отстающим товарищам.

Проф. РУДАКОВ: Отстающие студенты берутся на буксиры передовиками.

Доц. ЧЕРВОНЕЦКИЙ. Ежедневно ругаюсь со студентами по вопросам методов работы на 1-2 курсах. Студенты никак не могут усвоить, что они изучают ИНОЯЗЫК, что нужно прежде усвоить структуру языка - его грамматику. Неуспехи в нашей работе и зависят именно от того, что это основное положение студентами игнорируется. Фраза строится студентами по принципам русского синтаксиса. Получается разрыв между теорией и практикой. Студенты, зная теорию, не применяют ее на практике. Борьба с этим ненормальным положением пока не дает никаких результатов. Немногие студенты, следующие в учебе даваемому руководству, имеют прекрасные результаты. Это т.т. Пак на 2 к. (оба), Ян, Швайковский, Усачева, Ситнюк и Попова на 2 к. Как противоположный пример, упомяну Козыреву, кончившую Восточн. Институт в Харбине. Учится очень слабо, т. к не признает грамматику. Буксиры даются наилучшими передовиками: Хренов прикреплен к Швайковскому (теория) и Паку (практика). Передовики обмениваются лично своим опытом с товарищами.

<стр. 12> СТУД. ПРЕДСТАВИТЕЛИ. Кафедра не изучала системы и метода работы студентов, за исключением нескольких попыток со стороны т. Червонецкого выяснить как работают студенты и растолковать, как лучше работать. Как правило, таковое изучение отсут- 
ствует. Передача опыта работы передовиков отстающим проводилась исключительно по инициативе самих групп, кафедра ни в малейшей степени этим не интересовалась.

8. Посещения председателем кафедры занятий преподавателей. Доклады преподавателей на заседаниях кафедры. Организация открытых лекций и их обсуждения. Работа со студенческими представителями.

Проф. РУДАКОВ. Сам не имею возможности посещать занятия преподавателей, но в виде компенсации за это доц. Червонецкий на каждом очередном заседании кафедры делает обстоятельный доклад о состоянии работы кафедры в присутствии студенческих представителей, которые дополняют его своими сообщениями. Таким образом, мною достигается полная осведомленность. Все недочеты работы кафедра исправляет на ходу. Открытых лекций, в виду отсутствия подходящих интересных для студентов тем, не ведется и вестись в этом году не предполагается. Со студенческими представителями ведется работа в смысле ознакомления их с методами преподавания. Сами студ. представители обращаются с вопросами о методике преподавания. С ними ведутся беседы на тему кружковой работы (лингвистический кружок), о применении методов стахановского движения к умственной работе студентов (формы стахановского движения в улучшении и ускорении темпов изучения кит. языка). Намечены уже основные пункты и имеется в виду развитие работы по применению принципов стахановского движения в соответствующем направлении.

Доц. ЧЕРВОНЕЦКИЙ. Председатель кафедры не в состоянии посещать лекции по болезни. Я в свободное от лекций время посещаю занятия Чжана. Даю ему, как молодому еще преподавателю, методические указания по согласованию с теорией преподавания живой речи. Будучи экспансивной натурой, Чжан в то же время легко расхолаживается на уроках под влиянием недисциплинированного поведения студентов. Результатом этого бывают бессистемные занятия. Знаю, что здесь вина кроется в самих студентах. Чжан - ценный работник для университета. Хотя он и не имеет педагогического навыка, но он закончил Ленинскую школу во Владивостоке, знаком с классической литературой и интересуется современной литературой Китая.

СТУД. ПРЕДСТАВИТЕЛИ. НИ открытЫХ, ни закрытых лекций кафедрой не организовывалось. Научные кружки не создавались. Освещение преподавательской работы ограничивалось только докладами на заседаниях кафедры; дальше рамок кафедры оно не шло.

В заключении коснемся странного взгляда т. Червонецкого на причины срыва занятий т. Чжана. Вместо того, чтобы искать корни их в отсуствии каких либо прошраммных руководств и инструкций по этому поводу, т. Червонецкий видит главную причину зла в тех же «неблагонравных» студентах, хотя мною констатировалось уже вполне дисциплинированное (даже слишком вялое) поведение студентов на занятиях Чжана.

<стр. 13> 9. Руководство дипломантами со стороны кафедры.

Проф. РУДАКОВ. Студентам даются точные указания о формах использования материала. Темы сообщены дипломантам своевременно с предоставлением свободного выбора их. Руководство идет по 
двум линиям: 1) Указания общего характера и общего направления (общие методические основы). 2) Разъяснения по языку.

СТУДЕНЧЕСКИЕ ПРЕДСТАВИТЕЛИ. Руководство дИПЛомантами пока выразилось лишь в подыскании статей для дипломных переводов и в разработке тем для самостоятельных дипломных работ. С дипломантами прошлого выпуска кафедра не вела никакой систематической работы и не могла бы отвечать за качество их работ. Нужно сказать, что и в этом году кафедра навряд ли знакома с состоянием работ дипломантов на сегодняшний день.

10. Руководство производственной практикой студентов и итоги этой практики.

Проф. РУДАКОВ. Студентам, отправляющимся на производственную практику, даются соответствующие задания в письменной форме, содержащие необходимое руководство (цель практики, порядок ее прохождения). По окончании практики студенты представляют отчеты о своей работе, дневники, словарики изучаемых диалектов и т. д. На днях кафедрой организуется конференция о производственной практике, где будут поставлены все вопросы на обсуждение широкой студенческой общественности. Будут учтены успехи и недочеты для постановки производственной практики на правильное русло.

Доц. ЧЕРВОНЕЦКИЙ. Нужно констатировать, что удельный вес производственной практики у нас вообще очень мал. Подходящими местами для нее я считаю те, в которых имеется возможность тесного соприкосновения с образованными китайцами. Этих мест немного: 1) Ленинская (китайская) школа, 2) Клуб 1-го мая, 3) Редакция кит. газеты и 4) Кит. сектор КОГИЗа. Последние два берут с неохотой лишь 1-2 студента (стесненный бюджет зарплаты). Есть еще кит. колхозы, но по составу своих коллективов они не могут быть местами полноценной практики: здесь студенты больше учат, чем учатся. Имеющееся в Москве «Из-во иностранных рабочих» для нас слишком далеко. Отсюда вывод - необходимо извлечь необходимую пользу из мест наиболее насыщенной практики - Кит. Лен. Школы и Клуба 1-го мая. Основное здесь условие - студент сам должен искать места и объекта практики, а не ждать, когда случай представит ее. В Кит. Лен. Школе имеется солидны контингент образованных китайцев, которых можно широко использовать объектом для практики, несмотря на разницу в диалекте. Из пребывания в кит. колхозах также можно извлечь немалую пользу, но там студенты будут иметь дело с малообразованными людьми.

СТУДЕНЧЕСКИЕ ПРЕДСТАВИТЕЛИ. Руководство производственной практикой ограничивается раздачей программ-заданий. Оперативное руководство кафедры отсутствует.

11. Степень обеспеченности кабинетами и их использования.

Проф. РУДАКОВ. В Университете имеется кабинет Востоковедения. Вся активная работа студентов проводится в нем. Кабинет используется <стр. 14> насколько возможно. Словарей и учебных пособий нехватает. Необходимо обратить внимание деканата на то, что из выписываемых уже в течение ряда лет по заявке кафедры книг, журналов и газет на кит. языке мы почти ничего не получаем. 
Доц. ЧЕРВОНЕЦКИЙ. Кабинет имеется, но мы не получаем никакой свежей литературы на кит. языке, за исключением разрозненных №o журнала «Восток», отдельных номеров «Педагогического журнала» и отдельных №№ шанхайской газеты «Шэнь-бао». Весь этот поступаемый материал немедленно идет в обработку для лекционного текста на 3, 4, 5 курсах. Научные работники кафедры совершенно лишены возможности читать свежую китайскую литературу.

\section{2. Работа кафедры в направлении развития самостоятельности} студентов.

Проф. РУДАКОВ. На старших курсах студенты занимаются самостоятельным переводом свежих газетных вырезок. Желательно привитие навыков к самостоятельной лингвистической работе через научный кружок. Разъяснительная работа по организации лингвистического кружка ведется, но кружок еще не организован.

Доц. ЧЕРВОНЕЦКИЙ. Разговоры о создании кружка по углубленному изучению кит. языка успехов до сих пор не имели. Следует отметить, как единственный случай, работу студентки Усачевой (2 к.) сбор материалов для хрестоматии по теории языка. В текущем акад. году все попытки наладить организацию научного лингвистического кружка не имели успеха. Старшие курсы упорно отмахиваются от этой работы; 1-2 курсы собирались, но безуспешно. Недавно студентка Курицына $(2$ к.) начала под моим руководством составление небольшого словаря театральной терминологии, затем намерена перейти к лексике пьес, музыке и т. д.

13. Участие кафедры в разработке проблем по развитию производственных сил края (связь с соотвеств. организац.)

Проф. РУДАКОВ. Студенты, откомандированные для производственной практики в кит. колхозы ДВК имели возможность вести культурную работу, издавали там стенную газету для кит. рабочих, вели разнообразную общественную работу. На собраниях среди кит. трудящихся делались сообщения на современные политические темы. Более кафедра никакой работы в этой области не ведет.

14. Научно-исследовательская работа кафедры и участие в научных обществах.

Проф. РУДАКОВ. Научно-исследовательская работа кафедры изложена в учебно-производственном плане. По наметкам этого плана она и ведется. Доц. Червонецкий готовит к печати свою хрестоматию по военной терминологии. Я совместно с преподавателем Чжаном заканчиваю составление 2-й части «Учебника нового разговорного кит. языка» (1-я часть издана 2 года тому назад) Установка этого учебника разработана в представленной мною в Деканат Востфака записке «О новом учебнике китайского разговорного языка» (методические установки). Кроме этого учебника, я занят разработкой синтаксиса <стр. 15> кит. литературного языка, а также работой «О местоимениях кит. лит языка». Имеются в виду и другие работы. Кафедра не участвует в соответствующих научных обществах, ибо таковых в городе нет.

Доц. ЧЕРВОНЕЦКИЙ. Я обеспечиваю курсы Университета, на которых веду преподавание, учебными пособиями. За период 1927- 
33 г. г. кафедра пользовалась исключительно моими учебниками по теории разговорного языка на 1, 2 и 3 курсах. Военная терминология также преподается по моему учебнику. Содержание учебников, конечно, изменяется мною с течением времени. Жалая оказать посильную помощь за пределы Университета, пересоставляю теперь учебник военной терминологии для нужд Армии.

\section{5. Руководство научными кружками.}

Проф. РУДАКОВ. Кафедрой принимаются все меры к созданию научного лингвистического кружка, но пока конкретных результатов нет. Окончившей Востфак т. Медовой уже велась научно-исследовательская работа в преддипломном виде, несмотря на отсутствие научного кружка.

\section{6. Подготовка к зачетной сессии.}

Доц. ЧЕРВОНЕЦКИЙ. Кафедра на каждом очередном совещании мобилизует внимание студентов на необходимости систематической подготовки к зачетной сессии. Таким образом, подготовка к зачетной сессии идет планомерным путём с начала семестра, а не в порядке «кампании».

17. Методы соцсоревнования в работе кафедры.

Проф. РУДАКОВ. Имеется письменная наметка плана соцсоревнования[,] вызываемого кафедрой кит. языка. В прошлом году велось соцсоревнование между кафедрами китайского и японского языков. В этом году договор на соцсоревнование между обоими кафедрами не оформлен, но индивидуально члены кафедры соревнуются между собою в повседневной работе, не заключая формальных обязательств.

Доц. ЧЕРВОНЕЦКИЙ. Я соревнуюсь с доцентом кафедры японского языка, т. Юркевичем.

18. Работа кафедры по повышению квалификации своих членов.

Проф. РУДАКОВ. Принимая во внимание преклонный возраст и интенсивность научно-исследовательской работы большинства членов кафедры, никакой работы в этом направлении кафедрой не ведется.

\section{ЗАКЛЮЧЕНИЕ}

\section{СТУДЕНЧЕСКИЕ ПРЕДСТАВИТЕЛИ}

тов. ПОТАПОВ (4-й курс). По данному обследованию мною опрошены студенты: на 3-м курсе т. т. Ким, Ст., Козлов, Тарасов и Беловицкий. Мнения их совпадают с моей оценкой. Они оценивают работу кафедры как ПЛОХУЮ. Со своей стороны считаю, что кафедра кит. языка и в текущем и в прошлом году работала ПЛОХО.

<стр. 16> т. ДЕНИЩЕНКО (5-й к.) По данному обследованию мною опрошены студенты: на 1-м курсе - т. Вяткин. На 2-м курсе т. т. Соловьев, Пак, Петр, Волков и еще группа в несколько человек.

В отношении работы кафедры за текущий и прошлые годы нужно сказать, что студенты никогда не чувствовали существования кафедры, как организации, направляющей и определяющей их учебную 
жизнь. Кафедра рассматривалась, как учреждение чисто формальное, существующее для утверждения оценок, отчетов по производственной практике и т. д.

Оторванность руководителя кафедры от студенческой жизни привела к тому, что ряд серьезных вопросов проходил мимо кафедры. Например, составление учебного плана для 5-го курса, раскладка часов по дисциплинам этого плана и распределение поручений.

Считаю, что кафедра, помимо своих чисто формальных функций, еще является центром, организующим весь учебный процесс и учебную жизнь студентов. У нас же она остается формально существующей организацией, где руководитель еще не поставлен на свое должное место в силу ряда причин, не всегда от него зависящих, а в первую очередь, в силу невозможности самому непосредственно сталкиваться с жизнью факультета в целом и китайского его отделения - в частности.

ПРЕДСТАВИТЕЛЬ КАФЕДРЫ ЯПОНСКОГО ЯЗЫКА - НАУЧНЫЙ РАБОТНИК ФЕКЛИН. В настоящих «материалах по итогам обследования кафедры кит. языка Востфака ДВГУ» я поместил в их нетронутом виде следующие источники:

1. Личный опрос председателя кафедры проф. Рудакова и доц. Червонецкого по обследованию работы кафедры.

2. Личные записки о посещении мною лекций на 1, 2, 3, 4 и 5 курсах кит. отделения Востфака, а также запись доклада т. Червонецкого на заседании деканата Востфака 20/ XII.

3. Записи студенческих представителей т. Денищенко (5 к.) и т. Потапова (4 к.) по обследованию всех курсов кит. отделения Востфака.

4. Перечень взятых мною у секретаря деканата Востфака учебных программ.

Взвесив все имеющиеся передо мною материалы и учитывая все мною читанное, слышанное и виданное, я, принимая во внимание, как положительную сторону работы кафедры, большую эрудицию ее членов и проделывемую ими серьезную научно-исследовательскую работу, все-же не могу пройти мимо некоторых бьющих в глаза явлений, свидетельствующих о засилье в учебно-производственном процессе работы кафедры устаревших, формалистических методов работы. Эти методы и составляют на сегодня основу отрицательных сторон работы кафедры.

Считаю работу кафедры на сегодня не вполне отвечающей серьезным задачам, выдвинутым перед Востфаком и поэтому СЛАБОЙ.

Научный работник

ДВГУ

(Феклин)

31/XII-1935 г.

Владивосток

РГИА ДВ Ф. Р-289. Оп. 1. Д. 291. Л. 2-9 об. 